\title{
ANALISIS KOMPETENSI KEPRIBADIAN GURU PADA MADRASAH ALIYAH ASSALAM POLONGBANGKENG UTARA KABUPATEN TAKALAR
}

\author{
RURUNG, ARIFUDDIN SIRA, MUSDALIFAH \\ ASN Kementerian Agama Kabupaten Takalar \\ Universitas Islam Negeri Makassar \\ Email: muhjulqarnanin94@gmail.com, arifuddin.siraj@gmail.com, musdalifah@uin- \\ alauddin.ac.id
}

\begin{abstract}
:
This type of reserch is qualitative. In this study, researchers took the population of Aliyah Madrassah Assalam Timbuseng teachers, which totaled 6 people with a sample of 23 teachers. The results showed that personality competencies, teachers at MA AS-Salam, there are some teachers who meet the criteria that are indicators of personality competency, but there are also some teachers who still lack personality competency. To teachers who have very comptent personalities, students will be very respectful and even feel reluctant to the teacher concerned. In contrast to teachers whose personality competencies are still lacking students will tend to show less respect. The teacher in building personal relationship with students through many ways both in the classroom when the teaching and learning process takes place and outside the classroom. The Madrasah facilitates teachers to take part in activities related to competency enhacement, including by attending teacher upgrading, attending MGBS, and taking courses.
\end{abstract}

Keywords: Teacher Personality Competencies

\section{PENDAHULUAN}

endidikan selalu berkenaan dengan upaya pembinaan manusia, maka keberhasilan pendidikan sangat mempengaruhi perilaku dan sikap manusia dalam kehidupannya sebagai makhluk sosial. Unsur manusia yang paling menentukan berhasilnya pendidikan adalah pelaksana pendidikan, yaitu guru. Guru menjadi ujung tombak pendidikan sebab guru secara langsung berupaya mempengaruhi, membina, dan mengembangkan kemampuan siswa agar menjadi manusia yang cerdas, terampil, dan bermoral tinggi.

Di sekolah, guru hadir untuk mengabdikan diri kepada umat manusia, dalam hal ini anak didik. Negara menuntut generasinya yang memerlukan pembinaan dan bimbingan dari guru. Guru dan anak didik adalah sosok manusia yang tidak dapat dipisahkan dari dunia pendidikan. Boleh jadi, di mana ada guru di situ ada anak didik yang ingin belajar dari guru. Sebaliknya, di mana ada anak didik di sana ada guru yang ingin memberikan binaan dan bimbingan kepada anak didik. Guru dengan ikhlas memberikan apa yang diinginkan oleh anak didiknya. Tidak ada sedikitpun dalam benak guru pikiran negatif untuk tidak mendidik anakdidiknya, 
meskipun barangkali sejuta permasalahan sedang merongrong kehidupan seorang guru.

Guru adalah salah satu faktor utama dalam menetukan mutu Pendidikan, gurulah yang bersentuhan langsung dalam kelas, indikator ilmu pengetahuan dan teknologi, sekaligus menanamkan nilai-nilai positif melalui bimbingan dan uswatun hasanah. Dipundak guru jua lah akan lahir anak-anak didik yang bermutu tinggi baik secara kognitif, psikomotorik, afektif, serta spiritual. Oleh karena itu diperlukan seorang guru yang tidak hanya memiliki kualifikasi, kompetensi, dan dedikasi, tetapi memiliki pribadi yang menginspirasi anak didik.

Kompetensi guru merupakan kemampuan seorang guru dalam melaksanakan kewajiban-kewajiban secara bertanggung jawab dan layak. Kompetensi yang dimiliki oleh setiap guru akan menunjukkan kualitas guru dalam mengajar. Kompetensi tersebut aakan terwujud dalam penguasaan pengetahuan dan prosesional dalam menjalankan fungsinya sebagai guru. Artinya guru dituntut untuk memiliki kompetensi pedagogis, personal, professional, dan sosial.

Kepribadian guru dalam proses pembelajaran dapat mempengaruhi minat belajar anak didik terhadap pelajaran yang di berikan oleh guru. Suasana menyenangkan yang di rasakan oleh anak didik akan memperlancar proses pembelajaran, hal tersebut memberi andil sangat besar terhadap tercapainya tujuan pembelajaran. Oleh karena itu, minat dan bakat anak didik akan tumbuh mana kala guru membimbingnya memiliki kepribadian yang baik, menyyenangkan dan berwibawa.

Berdasarkan uraian di atas maka penulis merasa tertantang untuk mencoba meneliti aspek kompetensi kepribadian guru dalam melaksanakan manajemen kelas pada Madrasah Aliyah Assalam Polongbangkeng Utara Kab. Takalar. Sebagai sebuah lembaga pendidikan formal, Madrasah Aliyah Assalam tentu memiliki unsur-unsur pendidikan sebagaimana yang telah dipaparkan sebelumnya oleh penulis. Guru, Murid, dan infrastrukutur berupa kelas sebagai tempat belajar tentu sesuatu yang mutlak harus ada di Madrasah Aliyah Assalam Polongbangkeng Utara Kab. Takalar. Dalam konteks inilah penulis akan mencoba melakukan penelitian untuk mengungkap bagaimana gambaran kompetensi kepribadian guru di Madrasah Aliyah Assalam Polongbangkeng Utara kab. Takalar.

Dalam PP Nomor 19 tahun 2005 tentang Standar Nasional Pendidikan, penjelasan Pasal 28 ayat (3) butir b dikemukakan bahwa yang dimaksud dengan kompetensi kepribadian adalah kemampuan kepribadian yang mantap, stabil, dewasa, arif, dan berwibawa, menjadi teladan bagi peserta didik, dan berakhlak mulia. Kompetensi kepribadian merupakan kemampuan personal yang mencerminkan kepribadian yang mantap, stabil, dewasa, arif, dan berwibawa, menjadi teladan bagi peserta didik, dan berakhlak mulia. Secara rinci sub kompetensi tersebut dapat dijabarkan sebagai berikut: 
1. Kepribadian yang mantap dan stabil memiliki indikator esensial: bertindak sesuai dengan norma hukum; bertindak sesuai dengan norma sosial; bangga sebagai guru; dan memiliki konsistensi dalam bertindak sesuai dengan norma.

2. Kepribadian yang dewasa memiliki indikator esensial: menampilkan kemandirian dalam bertindak sebagai pendidik dan memiliki etos kerja sebagai guru.

3. Kepribadian yang arif memiliki indikator esensial: menampilkan tindakan yang didasarkan pada kemanfaatan peserta didik, sekolah, dan masyarakat serta menunjukkan keterbukaan dalam berpikir dan bertindak.

4. Kepribadian yang berwibawa memiliki indikator esensial: memiliki perilaku yang berpengaruh positif terhadap peserta didik dan memiliki perilaku yang disegani.Akhlak mulia dan dapat menjadi teladan memiliki indikator esensial: bertindak sesuai dengan norma religius (iman dan taqwa, jujur, ikhlas, suka menolong), dan memiliki perilaku yang diteladani peserta didik.

Secara rinci kompetensi kepribadian guru dapat digambarkan sebagai berikut:

a. Mantap, stabil, dan dewasa

Mantap berarti tetap; kukuh; kuat.Pribadi mantab berarti memiliki suatu kepribadian yang tidak tergoyahkan agar dapat melaksanakan tugasnya dengan baik, profesional dan bertanggung jawab.Stabil berarti mantap; kokoh; tidak goyah. Jadi pribadi stabil merupakan suatu kepribadian yang kokoh.Sedangkan dewasa secara bahasa sampai umur; akil; balig. Memiliki kepribadian yang mantap dan stabil, yang indikatornya bertindak sesuai dengan norma hukum, norma sosial. Memiliki kepribadian dewasa dengan ciri-ciri, menampilkan kemandirian dalam bertindak sebagai pendidik yang memiliki etos kerja, dapat melaksanakan tugasnya dengan baik, profesional dan dapat dipertanggung jawabkan, guru harus memiliki kepribadian yang mantap, stabil dan dewasa.

\section{b. Arif dan Berwibawa}

Arif dapat berarti bijaksana; cerdik; pandai; berilmu; mengetahui. Memiliki kepribadian arif, yang ditunjukan dengan tindakan yang bermanfaat bagi peserta didik, sekolah dan masyarakat serta menunjukan keterbukaan dalam berfikir dan bertindak. Guru bukan hanya menjadi seorang manusia pembelajar tetapi menjadi pribadi bijak, seorang saleh yang dapat mempengaruhi pikiran generasi muda.

c. Menjadi teladan

Guru merupakan teladan bagi para peserta didik dan semua orang yang beranggapan dia sebagai guru. Pribadi guru sangat berperan dalam membentuk pribadi peserta didik. Ini dapat dimaklumi karena manusia merupakan makhluk yang suka mencontoh, termasuk mencontoh pribadi gurunya dalam membentuk pribadinya. Secara teoritis, menjadi teladan merupakan bagian integral dari seorang guru, sehingga menjadi guru berarti menerima tanggung jawab menjadi teladan. 


\section{d. Berakhlak Mulia}

Arahan pendidikan nasional ini hanya mungkin terwujud jika guru memiliki akhlak mulia. Siswa terbentuk menjadi siswa yang berakhlak mulia karena guru, sebab guru menjadi cerminan bagi setiap muridnya.

Menurut Husain dan Ashraf, "Dalam dunia kontemporer saat ini perhatian lebih ditunjukan pada bangunan, peralatan, perlengkapan, dan materim dibandingkan kepribadian dan karakter guru".Sebuah kritik yang telah diutarakan perlu dijadikan perbincangan hangat bagi setiap manajemen lembaga pendidikan dan fakultas pencetak calon guru.

e. Mengembangkan diri

Di antara sifat yang harus dimiliki guru ialah pembelajar yang baik atau pembelajar orang dengan jumlah sampel 23 orang mandiri, yaitu semangat yang besar untuk menuntut imu. Sebagai contoh kecil yaitu kegemarannya membaca dan berlatih keterampilan yang dapat menunjang peofesinya sebagai pendidik. Berkembang dan bertumbuh hanya dapat terjadi jika guru mampu konsisten sebagai pembelajar mandiri, yang cerdas memanfaatkan fasilitas pendidikan yang ada di sekolah dan lingkungannya.

\section{METODE PENELITIAN}

Jenis penelitian ini adalah kualitatif. Pada lokasi penelitian bertempat di Madrasah Aliyah Assalam Polongbangkeng Utara. Pada penelitian ini, peneliti mengambil populasi para guru Aliyah Madrasah Assalam Timbuseng yang berjumlah secara keseluruhan 56 guru. Pendekatan yang digunakan dalam penelitian ini adalah pendekatan fenomenologi, pendekatan paedagogik, pendekatan sosiologis, pendekatan filosofis empiris, pendekatan teologis normatif, dan pendekatan yuridis. Data dikumpulkan dengan menggunakan metode wawancara, observasi, dan dokumentasi dengan instrumen pedoman wawancara, pedoman observasi dan alat dokumen seperti kamera dan HP.

\section{HASIL PENELITIAN DAN PEMBAHASAN}

\section{A. Kompetensi Guru MA As-salam}

1. Integritas dan Keteladanan Guru

Integritas dan keteladanan guru sangat penting dan menentukan dalam keberhasilan pelaksanaan manajemen kelas sebagai proses mencapai tujuan pendidikan. Berdasarkan Penjelasan Peraturan Pemerintah No 19 Tahun 2005 tentang Standar Nasional Pendidikan disebutkan bahwa kompetensi kepribadian guru yaitu kemampuan kepribadian yang: (1) mantap; (2) stabil; (3) dewasa; (4) arif dan bijaksana; (5) berwibawa; (6) berakhlak mulia; (7) menjadi teladan bagi peserta didik dan masyarakat; (8) mengevaluasi kinerja sendiri; dan (9) mengembangkan diri secara berkelanjutan. Berdasarkan wawancara peneliti dan hasil observasi 
yang dilakukan di MA As-Salam, kesembilan kompetensi kepribadian tersebut masih belum maksimal dicapai dalam karakter integritas guru di MA As-Salam.

Menurut Sulaiman Unjung, Kepala MA As-Salam ada beberapa guru yang memenuhi criteria tersebut, namun ada juga beberapa guru yang masih kurang kompetensi kepribadiannya, khususnya pada beberapa aspek tertentu. Sulaiman Unjung mencontohkan ada dua guru yang apatis dalam mengajar dan ada pula dua guru yang sangat tidak disiplin dalam mengajar dengan indikasi seringnya mereka terlambat masuk pada jam mata pelajaran mereka. Sulaiman Unjung menyebut ada tiga guru yang sanga ttegas dan berwibawa utamanya ketika mereka mengajar di kelas. Secara umum menurut Sulaiman Unjung, ia melihat guru-guru di MA AsSalam selalu berusaha menjaga kompetensi kepribadiannya di hadapan para siswa, meski pada beberapa hal masih perlu ditingkatkan dan dibenahi, utamanya pada beberapa oknum guru yang belum menampilkan sikap kompetensi kepribadian yang sesuai kepada peserta didiknya.

Menurut Darmawati, S. Ag, Waka Bidang Kurikulum guru sebagai tenaga pendidik harus berusaha mewujudkan karakter kompetensi kepribabdian yang mantap, stabil, dewasa, arif dan berwibawa, menjadi teledan bagi peserta didik dan berakhlak mulia. Guna mewujudkan kompetensi kepribadian tersebut dirinya selalu berusaha menjaga muruah pribadi khususnya di hadapan siswa. Menurut Darmawati, sedikit saja guru lalai darikmpetensi pribadi tersebut, maka akan berdampak fatal bagi pembentukan kepribadian siswa, sebagaimana kata pepatah; "guru kencing berdiri, murid kencing berlari". Menurut Darmawat, guru yang berkelakuan baik adalah memiliki kepribadian yang baik, atau berakhlak mulia. Sebaliknya, jika guru memiliki perilaku dan perbuatan buruk atau tidak baik menurut pandangan norma etika dan agama, maka guru tersebut tidak memiliki kepribadian yang baik atau mempunyai akhlak yang tidak mulia. Oleh karenanya, kerpibadian guru menjadi menjadi barometer tentang tinggi rendahnya kewibawaan guru dalam pandangan peserta didik bahkan di mata masyarakat.

Menurut Abdul Rahman, S. Pd Waka bidang Sarana dan Pra-Sarana mengatakan guru merupakan cerminan atau panutan hidup bagi peserta didiknya, oleh karenanya guru harus mampu memiliki dan menampilkan sikap sebagai panutan yang mantap, berwibawa dan berakhlak mulia. Karakter tersebut mesti terimplementasi dalam sikap tegas danmenjaga muruah utamanya di hadapan para siswa. Implementasi kompetensi tersebut, ia berusaha menampilkan kemandirian, komitmen ketegasan dalam bertindak sebagai pendidik dan memiliki etos kerja guru yang disiplin dan bijaksana.

Menurut Paharuddin, S.Pd, guru mata pelajaran Sosiologi mengatakan dalam membentuk Kepribadian yang mantap dan stabil ia berusaha bertindak sesuai dengan norma etika dan sosial yang berlau, menumbuhkan rasa bangga menjadi guru, dan memiliki komitmen dan istiqamah dalam bertindak sesuai dengan norma. Sebagai seorang guru perlu membentuk kepribadian yang dewasa dengan 
menampilkan kemandirian dalam bertindak sebagai pendidik dan memiliki etos kerja yang tinggi sebagai guru. Menurut Paharuddin, Kepribadian arif yang dimiliki oleh seorang guru adalah dengan menunjukkan tindakan yang didasarkan pada asas kemamfaatan peserta didik, sekolah dan masyarakat serta menunjukkan sikap keterbukaan dalam berpikir dan bertindak. Untuk itu, ia selalu berusaha menempatkan siswanya dengan pendekatan yang lebih dewasa dengan tanpa menafikan sikap tegas dan berwibawa. Untuk itu menurut Paharuddin, seorang guru harus berusaha tampil dengan kepribadian yang berwibawa yaitu dengan memiliki perilaku yang berpengaruh positif terhadap peserta didik dan menjadi pribadi yang disegani. Mewujudkan sikap berwibawa tersebut berkaitan erat dengan kepribadian akhlak mulia yaitu kemampuan bertindak sesuai dengan aturan agama daoral yang dapat diteladani oleh para siswa.

1. Sikap dan Pola Hubungan antara Guru dan Siswa

Salah satu faktor yang sangat mempengaruhi bagi keberhasilan guru dalam proses pelaksanaan manajemen kelas dan tercapainya tujuan pembelajaran adalah hubungan personal yang terbangun antara guru dan para siswanya. Para guru di MA As-Salam senantiasa berusaha untuk membangun hubungan personal (personality relationship) yang baik dengan siswa atau santrinya. Guru yang berkualitas juga harus mampu bersosialisasi dengan peserta didik, sesama guru, pihak pimpinan sekolah, komite sekolah, orang tua maupun masyarakat sekitar tempat tinggalnya dengan baik. Berdasarkan data yang peneliti dapatkan baik melalui hasil wawancara maupun pengamatan lanngsung menunjukkan adanya hubungan personal yang baik terbangun antara para guru dengan siswa atau santri mereka di MA As-Salam. baik di ruang kelas saat proses belajar mengajar berlangsung maupun di luar kelas dalam lingkungan madrasah.

Hubungan baik secara personal antara guru dan siswa di MA As-Salam diakui oleh sejumlah siswa yang peneliti temui. Diantaranya Mursalim siswa kelas XII, mengatakan bahwa guru dalam membangun hubungan personal kepada para siswa melalui banyak cara baik di dalam kelas ketika proses belajar mengajar berlangsung maupun diluar kelas. Hubungan personal yang terbangun di luar kelas misalnya melalui kegiatan organisasi pramuka dan melalui kegiatan olahraga seperti futsal dan voli. Melalui kegiatan tersebut para guru membangun sebuah relasi personal dengan para siswanya dengan suasana yang lebih rileks dan santai, meski demikian paa guru tetap memahami batas-batas hubungan antara guru dan siswa, demikian pula para siswa cukup mengerti batas-batas yang tak boleh dilampaui ketika bergaul dengan guru mereka. Menurut Mursalim para siswa tetap menjaga sikap hormat mereka sebagai seorang murid kepada gurunya, demikian pula sebaliknya para guru membangun hubungan personal selayaknya hubungan personal antara orang tua dan anaknya.

Nur Islamiyah, seorang siswi MA As-Salam menyatakan para guru sebagian besar berhasil membangun hubungan personal yang baik dengan para siswanya. 
Hubungan personal tersebut tidak hanya berkenaan dengan materi pelajaran melainkan hubungan seorang pendidik dengan anak didiknya yang mengajari sikap kedewasaan, kemandirian, kreativitas dan kasih-sayang. Menurut Nur Islamiyah, selama ia belajar di MA As-Salam ada banyak pengalaman yang ia dapatkan, diantaranya adalah belajar hidup sederhana, bagaimana hidup mandiri dan yang lebih mengesankan katanya adalah dalam menuntut ilmu seseorang harus belajar sabar dan berkorban. Hal itu semua ia dapatkan dari hasil didikan para guru yang mendidik dengan keteladanan serta hubungan personal yang komunikatif dan senantiasa memotivasi siswanya untuk lebih giat. Hasil dari pola pendidikan melalui pola hubungan personal yang dibangun oleh para guru sangat ia rasakan manfaatnya dan sangat berguna bagi pembentukan karakter dirinya dan semangat dalam belajar.

Menurut Ibu Darmawati, tugas utama seorang guru adalah mengembangkan segenap potensi siswanya secara optimal agar mereka dapat menjadi manusia yang mandiri, cerdas, dan taat beragama. Hubungan personal yang dibangun dengan siswa baik di dalam maupun di luar kelas merupakan konsekuensi logis dari tugas yang diemban oleh seorang guru. Menurut Darmawati, interaksi antara dirinya selaku guru dengan siswa atau santri MA As-Salam adalah dengan membangun komunikasi yang aktif dan intensif, membangun kedekatan emosional bagai seorang ibu dengan anak-anaknya. Secara pribadi ia membangun hubungan personal dengan siswa dilandasi rasa kasih-sayang dan menghidnarkan diri dari tindakan kekerasan fisik. Dalam membangun hubungan personal kata Darmawati dirinya selalu berusaha untuk bersikap tegas namun tidak dengan cara-cara kekerasan. kode etik dan profesionalisme guru menjadi pemandu arah bagi dirinya dalam membangun hubungan personal dengan para siswa.

Menurtu Sulaiman Unjung, upaya saya selaku kepala madrasah dan guru dalam membangun hubungan personal yang baik dengan para siswa adalah dengan mengajar di kelas dan upaya lain dengan melalui kegiatan keorganisasian (diantaranya pramuka) dan melalui kegiatan keolaragaan (diantaranya futsal) serta dengan cara mengajak para siswa dan guru untuk camping atau berkemah. Melalui kegiatan-kegiatan tersebut terbangun hubungan keakraban antara guru dan siswa, sehingga satu sama lain saling tumbuh rasa kedekatan dan kasih-sayang. Demikian pula dalam proses belajar-mengajar di kelas, para guru di MA As-Salam selalu berusaha membangun suasana kelas yang kondusif sehingga proses belajarmengajar dapat berlangsung dengan efektif. Selaku kepala madrasah, Sulaiman mengakui masih ada beberapa guru yang belum maksimal dalam hal tersebut, namun secara umum sebagian besar guru telah berhasil membangun pola hubungan dan komunikasi yang baik dengansiswanya baik dalam proses belajarmengajar maupun diluar proses tersebut.

Selaku kepala madrasah, Sulaiman juga membangun hubungan personal dengan guru dan siswa. Adapun membangun hubungan personal dengan guru 
adalah bercanda gurau pada saat makan siang di sekolah serta melalui kegiatankegiatan sekolah baik yang bersifat formal maupun non formal. Berdasarkan wawancara dengan beberapa guru, misalnya bapak Suhaebah, mengatakan bahwa kepala madrasah masih kurang produktif dalam membangun hubungan tersebut, sebab beliau memiliki kesibukan lain yakni sebagai kepala desa Timbuseng. Begitu pun penilain guru seperti ibu Hijrah dan Haisah yang menilai kepala madrasah masih belum optimal dalam membangun hubungan personal baik dengan guru maupun siswa dikarenakan kesibukannya yang lain.

2. Inovasi dan Peningkatan kompetensi

Pada MA As-Salam, guru dalam meningkatkan kompetensi pendidik yang professional dilakukan dengan beberapa hal yang berkaitan langsung dengan peningkatan kapasitas dan kompetensi mereka selaku pendidik. Menurut para guru yang peneliti wawancarai, mereka mengakui bahwa meski dengan segala keterbatasannya, pihak madrasah memotivasi dan memfasilitasi mereka untuk mengikuti kegiatan-kegiatan pelatihan dan sejenisnya yang berorientasi pada peningkatan kapasitas dan kompetensi guru baik berkenaan dengan peningkatan penguasaan materi pelajaran yang dibawakannya maupun meningkatan kompetensi pendidik lainnya.

Menurut Sulaiman Unjung, pihak madrasah memfasilitasi para guru untuk mengikuti kegiatan yang berkenaan dengan peningkatan kompetensi tersebut. Diantaranya dengan mengikuti penataran guru. Penataran dilakukan dengan peluang untuk guru-guru sebagai pengembangan professional untuk meningkatkan kemampuan guru dalam proses belajar mengajar. Penyelenggaraan penataran sebagai peningkatan kompetensi dilakukan dengan beberapa cara: pertama sekolah bekerja sama dengan sekolah-sekolah lain yang sama-sama membutuhkan penataran sebagai upaya peningkatan kapasitas dan kompetensi guru. Kedua sekolah mengirim atau mengutus guru untuk mengikuti penataran yang dilakukan sekolah lain atau lembaga depertemen yang membawahi.

Selain mengikuti penataran, para guru juga Mengikuti MGBS (musyawarah guru bidang studi). MGBS dimaksudkan untuk menyatukan dengan konsepsi yang kurang dan mengkombinasikannya dengan kekurangan yang ada. Selain itu juga mendorong para guru melakukan tugas dengan baik, sehingga mampu meningkatkan kompetensinya. Keterlibatan para guru dalam MGBS secara langsung dirasakan melalui peningkatan penguasaan mereka atas materi mata pelajaran yang dibawakannya. Sebagaimana yang disampaikan oleh Suhaebah, guru mata pelajaran Bahasa Indonesia, menurutnya keterlibatan dalam MGBS membantu dia dalam meningkatkan penguasaan materi pelajaran dan strategi pengajaran Bahasa Indonesia di kelas. Menurut Suhaebah madrasah dalam hal ini cukup membantu memfasilitasi dan memotivasi dirinya dan gurulainnya untuk aktif dalam kegiatan MGBS. Penuturan yang sama disampaikan oleh beberapa guru yang peneliti wawancarai, diantaranya Paharuddin guru sosiologi dan Lewardi guru 
mata pelajaran sejarah. Keduanya mengakui bahwa pihak madrasah dan Kementerian Agama Kabupaten Takalar proaktif melibatkan para guru di MA AsSalam dalam setiap kegiatan MGBS dari masing-masing bidang studi.

Pihak madrasah juga membantu memfasiltasi para guru untuk meningkatkan kapasitas dan kompetensi dengan mengikutkan mereka dalam kegiatan kursuskursus tertentu yang sesuai dengan bidang mereka. Merupakan suatu kursus tersebut untuk membantu guru dalam mengembangkan pengetahuan sesuai dengan keahlian dan bidang studinya masing-masing. Menurut Nurwahidah Latif guru mata pelajaran Bahasa Inggris, mengatakan bahwa madrasah sangat menfasilitasi dengan baik dalam membantu peningkatan kompetensi guru dalam mendidik, misalnya dengan memberikan anggaran secukupnya bagi guru yang mengikuti kursus maupun pada saat mengikuti penataran guru. Pemberian anggaran untuk kegiatan peningkatan kapasitas dan kompetensi guru tersebut diakui oleh Sulaiman Unjung selaku kepala madrasah. Menurut Sulaiman, pihak madrasah senantiasa mengalokasikan dana bagi peningkatan kapasitas dan kompetensi guru. Diakui oleh Sulaiman alokasi dana tersebut masih belum maksimal karena kondisi keuangan madrasah yang masih minim, namun setidaknya sebagai bentuk kepedulian dan keseriusan pihak pimpinan madrasah dalam hal peningkatan kualitas madrasah dengan meningkatkan kualitas tenaga pendidiknya.

Selain melalui dukungan lembaga, peningkatan kompetensi guru juga berkaitan erat dengan upaya yang dilakukan oleh guru yang bersangkutan sendiri dalam meningkatkan kualitas kompetensinya selaku tenaga pendidik. Peningkatan kompetensi selaku tenaga pendidik adalah melalui peningkatan pengetahuan melalui pemanfaatan media dan teknologi. Menurut Darmawati, seorang guru tidak cukup mempelajari atau mendalami dari buku-buku yang ada, melainkan memerlukan media tambahan sebagai pendukung dalam meningkatkan kualitas dalam proses belajar mengajar. Salah satu media yang cukup membantu dalam meningkatkan profesionalisme guru dalam proses belajar mengajar adalah media cetak dan media elektronik. Hal ini akan membawa pemikiran-pemikiran baru dan wawasan-wawasan baru bagi seorang guru dalam pengajaran. Menurut Darmawati, dirinya selalu memanfaatkan pengetahuan dari media baik media konvensional maupu nmedia online seperti internet. Pemanfaatan media dalam peningkatan kapasitas selaku tenaga pendidik dirasakan langsung oleh dirinya karena banyak hal dan pengetahuan baru yang ia dapat melalui informasi dari media tersebut.

\section{PENUTUP/SIMPULAN}

Berkenaan dengan kompetensi kepribadian, guru di MA As-Salam, ada beberapa guru yang memenuhi kriteria yang menjadi indikator kompetensi kepribadian, namun ada juga beberapa guru yang masih kurang kompetensi kepribadiannya. Kepada guru yang memiliki kepribadian yang sangat kompeten, 
maka para siswa akan sangat hormat bahkan muncul rasa segan kepada guru yang bersangkutan. Sebaliknya kepada guru yang kompetensi kepribadiannya masih kurang siswa akan cenderung kurang menunjukkan sikap penghormatannya. Guru dalam membangun hubungan personal kepada para siswa melalui banyak cara baik di dalam kelas ketika proses belajar mengajar berlangsung maupun di luar kelas. Pihak madrasah memfasilitasi para guru untuk mengikuti kegiatan yang berkenaan dengan peningkatan kompetensi, diantaranya dengan mengikuti penataran guru, mengikuti MGBS, dan mengikuti kursus.

\section{DAFTAR PUSTAKA}

Arikunto, Suharsimi. Prosedur Penelitian Suatu Pendekatan Praktek, Edisi Revisi V Cet. XII; Jakarta: PT Asdi Mahasetya, 2002.

Analisis Kamus Besar Bahasa Indonesia Online, http://kbbi.web.id/analisis (2 Mei 2017.

A.Partanto, Pius \& al-Barry, M.Dahlan. Kamus IImiah Populer. Surabaya : Arkola, 1994.

Ahmadi, Abu \& Joko Prasetyo, Tri. SBM Strategi Belajar Mengajar Untuk Fakultas Tarbiyah Komponen MKDK. Bandung: CV. Pustaka Setia, 2005.

Brophy, Jere. dalam Vern Jonrs dan Loise Jones. terj. Intan Irawati, Manajemen Kelas Komprehensip. Cet. IX; Jakarta: Kencana Prenada Media Grup, 2004.

Djamarah, Syaiful Bahri. Guru dan Anak Dididik Dalam Interaksi Edukatif: Suatu Pendekatan Teoritis Prsikologis. Cet. III; Jakarta: Rineka Cipta, 2010.

Danim, Sudarwan. Etika dan Pengembangan Profesionalitas Guru. Cet. I; Makassar: Alauddin University Press.

Daradjat, Zakiyah. Kepribadian Guru. Cet. IV; Jakarta: Bulan Bintang, 2005.

Djamarah, Syaiful Bahri. Guru dan Anak Didik Dalam Interaksi Edukatif. Jakarta: Rineka Cipta, 2000.

Daradjat, Zakiyah. Kepribadian Guru. Cet. IV; Jakarta: PT. Bulan Bintang, 2005.

Hadi, Sutrisno. Metodologi Research. Jilid I, Cet. XX; Yogyakarta: Audi Ofsser, 1987.

Herdiansyah, Haris. Metodologi Penelitian Kualitatif untuk IImu IImu Sosial. Jakarta: Salemba Humanika, 2015.

Jones, Vern \& Jones, Louise. “Manajemen Kelas Koprehensif”. Cet. I; Jakarta: Kencana Prenada Media Grup, 2012.

Kementrian Agama RI. Al-Qur'an dan Terjemahannya. Bandung; PT Syaamil Cipta Media.

Kemenag Jatim "Peraturan Menteri Agama Repoblik Indonesia Nomor 29 Tahun 2014" https://jatim.kemenag.go.id/file/file/PMA/drin1412150101.PDF (3 April 2018. 
Mudjiono. Belajar dan Pembelajaran. Jakarta : Rineka Cipta, 1999.

Mulyasa, E. Manajemen Berbasis Sekolah Konsep, Strategi, Dan Implementasi. Bandung: PT. Remaja Rosdakarya, 2002.

Moleong, Lexy. Metodologi Penelitian Kualitatif. Cet. II; Bandung: Remaja Rosdakarya, 2006.

M. Echols John dan Shadiliy, Hassan. Kamus Inggris Indonesia. Cet. XXIII; Jakarta: Gramedia, 1996.

Musbahaeri. Urgensi Pengelolaan Kelas Dalam Meningkatkan Efektifitas Pembelajaran Pendidikan Agama Islam di SMA Negeri 1 Majauleng, Kab. Waja, Sulawesi Selatan, “Tesis” Universitas Islam Negeri Alauddin Makassar, 2009.

Musfah, Jejen. Peningkatan Kompetensi Guru Melalui Pelatihan dan Sumber Belajar Teori dan Praktik. Cet. I; Jakarta: Kencana Prenada Media Grup, 2011.

Nawawi, Hadari. Organisasi Sekolah dan Pengelolaan Kelas Sebagai Lembaga Pendidikan. Jakarta: Gunung Agung, 1982.

Nawawi, Hadari. Organisasi Sekolah dan Pengelolaan Kelas. Jakarta: CV. Haji Masagung, 1989.

Nazir, Moh. Metode Penelitian. Cet. III; Jakarta: Ghalia Indinesia, 1988.

Nurbaya. Analisis Kompetensi Guru Pendidikan Agama Islam pada SD Negeri di Kecamatan Marawola Kab. Sigi Sulawesi Tengah “Tesis” Universitas Islam Negeri Alauddin Makassar, 2012.

PP Nomor 19 tahun 2005, http://peraturan.go.id/inc/view/11e4eb77760a0861. 28 Mei 2018.

Rahman, Maman. Manajemen Kelas, Proyek Pendidikan Guru Sekolah Dasar. Jakarta: Dirjen Dikti Depdikbud.

Ridwan. Skala Pengukuran Variabel-Variabel Penelitian. Cet. I; Bandung, 2005.

Sukmadinata, Nana Syaodih. Metode Penelitian Pendidikan. Cet. I; Bandung: Remaja Rosdakarya, 2007.

Sudirman N. IImu Pendidikan. Bandung: Remadja Karya CV, 1987.

Sugiyono. Memahami Penelitian Kualitatif. Cet. III; Bandung: Alvabeta, 2005.

Salim, Agus. Teori dan Paradigma Peneletian Sosial. Yogyakarta: Tiara Wacana, 2006.

Sukmadinata, Nana Syaodih. Metode Penelitian Pendidikan. Cet. III; Bandung: Remaja Rosdakarya, 2007.

Tim Penyusun Kamus Pusat Bahasa. Kamus Besar Bahasa Indonesia. ed. 3; Cet. III; Jakarta, Balai Pustaka, 2007. 
RURUNG, ARIFUDDIN SIRAJ, MUSDALIFAH

Teguh, Muhammad. Metodologi Penelitian Ekonomi Teori dan Aplikasi. Cet. III; Jakarta: PT.Raja Grafindo Persada, 2005.

Yamin, Martinis \& Maisah. Manajemen Pembelajaran Kelas Strategi Meningkatkan Mutu Pembelajaran. Jakarta: Gaung Persada Press, 2009. 